\title{
Sensory evaluation and antimicrobial activity of snack bar from black soybean and black rice containing anthocyanins
}

\author{
1,*Pramitasari, R., ${ }^{2}$ Ariela, C. and ${ }^{3}$ Waturangi, D.E. \\ ${ }^{1}$ Department of Food Technology, Faculty of Biotechnology, Atma Jaya Catholic University of Indonesia, \\ Cisauk, Tangerang, Banten, Indonesia 15345 \\ ${ }^{2}$ Department of Biotechnology, Faculty of Biotechnology, Atma Jaya Catholic University of Indonesia, \\ Cisauk, Tangerang, Banten, Indonesia 15345 \\ ${ }^{3}$ Department of Master in Biotechnology, Faculty of Biotechnology, Atma Jaya Catholic University of \\ Indonesia, Cisauk, Tangerang, Banten, Indonesia 15345
}

\section{Article history:}

Received: 31 December 2020

Received in revised form: 16

February 2021

Accepted: 29 May 2021

Available Online: 5

December 2021

Keywords:

Antimicrobial activity, Anthocyanins,

Black rice,

Black soybean,

Snack bar

DOI:

https://doi.org/10.26656/fr.2017.5(6).776

\begin{abstract}
Snack bars made from black soybean and black rice could be used as a food product to complement the energy and nutrients needs. Both have anthocyanins content in black soybean and black rice as well as the potential as an antimicrobial agent. The purpose of this study was to obtain an optimal formula, evaluate the sensory acceptance, analyze the total monomeric anthocyanin content of the snack bars, and compare the growth of probiotic and pathogenic bacteria in anthocyanins crude extracts from the snack bars. The production of snack bars was done by using three variations of main ingredients, including $30 \%$ of black soybean $+70 \%$ of black rice (formula 1), $50 \%$ of black soybean $+50 \%$ of black rice (formula 2), and $70 \%$ of black soybean $+30 \%$ of black rice (formula 3 ). The results performed that consumers acceptance for formulas 2 and 3 was not significantly different $(\mathrm{P}>0.05)$, but significantly higher $(\mathrm{P}<0.05)$ than formula 1 . Total monomeric anthocyanin content analyzed by the $\mathrm{pH}$ differential method in these three snack bars formulas had no significant difference $(\mathrm{P}>0.05)$. The growth analysis of probiotic and pathogenic bacteria showed that the percentage of growth inhibition of Escherichia coli and Salmonella enterica serovar Typhi bacteria was significantly higher $(\mathrm{P}=0.00)$ compared to Lactobacillus acidophilus. Also, formulas 1 and 2 could significantly inhibit $E$. coli and $S$. enterica ser. Typhi bacteria $(\mathrm{P}=0.00)$ compared to formula 3 . It could be concluded that formula 2 showed the best snack bar based on sensory evaluation and pathogenic bacteria inhibition assay.
\end{abstract}

\section{Introduction}

Along with the development of the times, human awareness for a healthier life is increasing. Based on a survey conducted by the International Food Information Council (2016), Americans tried to increase their food consumption to $64 \%$ protein, $60 \%$ fibre, $33 \%$ probiotics, and $12 \%$ prebiotics compared to the previous year. Also, $41 \%$ of respondents said that healthy food is considered a food that contains little or no preservatives.

Anthocyanins are an important bioactive compound of flavonoids (Pervaiz et al., 2017). It is also found in black soybean and black rice (Pang et al., 2018; Lee et al., 2020). Anthocyanins are known to have antimicrobial activity with the mode of action disrupting the cell wall of the bacteria (Ma et al., 2019).
Antimicrobial activity recovered from plant extract are potentially natural preservative agents (Thielmann et al., 2017). Conversely, research on black soybean and black rice for this matter is still limited. Therefore, studies on anthocyanin in black soybean and black rice are required for further exploration of their application as a natural preservative.

In this globalization era, humans are demanded to be more efficient and faster in working. They require high nutritional food products that are easy to consume, such as snacks. Based on a survey conducted by The Nielsen Company (2014), in the Asia Pacific, 55\% of respondents said snacks were used as a substitute for breakfast, $39 \%$ as a substitute for lunch, and the rest regard as a substitute for dinner. Also, healthy snacks with natural ingredients, low salt, low sugar, and high 
fibre are preferred by consumers.

One of the high nutritional food products that are easy to consume is a snack bar. This food product could contain natural ingredients, such as nuts and seeds. Snack bar has become a healthy food trend and is high in energy. In Indonesia, commercial snack bar products are still limited. However, according to the Euromonitor survey, snack bar sales growth in Indonesia increased from 2014 by 15\% (Euromonitor International, 2020). These phenomena become great opportunities to increase and modify snack bar production and sales in Indonesia. Thus, a healthier snack bar black soybean, as well as black rice, could be the right option to be developed.

In a previous study, snack bars developed from the combination of black soybean and black rice for lactation mothers. This study mainly focused on isoflavone content, nutritional, physical, and sensory characteristics of these snack bars. However, the effect of anthocyanin in these snack bars as an antimicrobial agent has not been investigated yet (Pramitasari et al., 2018). Hence, this study is aimed to obtain an optimal formula, evaluate the sensory acceptance, analyze the total monomeric anthocyanin content of the snack bars, and compare the growth of probiotic and pathogenic bacteria in anthocyanin crude extracts from the snack bars.

\section{Materials and methods}

\subsection{Materials}

The main ingredients used in making snack bars were commercial black soybean bought from a local seller in Yogyakarta, Indonesia, and commercial black rice from Cianjur, Indonesia. Other ingredients were refined sugar, butter, raisins, choco chips, walnuts, almonds, granola, and vanilla flavour bought from a local market in Tangerang, Indonesia. Analytical grade chemicals that have been used were methanol, $\mathrm{HCl}$, buffer solution $\mathrm{pH} 1.0$ and $\mathrm{pH}$ 4.5. For antimicrobial activity assay, we used Lactobacillus acidophilus ATCC $(314$, Escherichia coli ATCC $(25922$, Salmonella enterica ser. Typhi from Atma Jaya Catholic University of Indonesia culture collection, physiological salt, anaerogen gas pack (Oxoid, UK), de Man, Rogosa, Sharpe Agar (MRSA) (Oxoid CM 361, UK), de Man, Rogosa, Sharpe Broth (MRSB) (Oxoid CM 359, UK), Nutrient Agar (NA) (Oxoid CM 2, UK), and Nutrient Broth (NB) (Oxoid CM 1, UK).

\subsection{Snack bars production}

Firstly, black soybean and black rice flour were prepared by grounding until it reached the consistency of flour and was sifted with a size of 80 mesh. Then they were packed with a plastic zipper and stored at room temperature for further use. A snack bar was made according to Pramitasari et al. (2018). It contained $50 \mathrm{~g}$ of soy flour and black rice flour, $25 \mathrm{~g}$ of refined sugar, $15 \mathrm{~g}$ of butter, $10 \mathrm{~g}$ of raisins, $5 \mathrm{~g}$ of choco chips, $5 \mathrm{~g}$ of walnuts, $5 \mathrm{~g}$ of almonds, $5 \mathrm{~g}$ of granola, $2 \mathrm{~g}$ of flavour vanilla, and $8 \mathrm{~mL}$ of water. The ratio variations of black soybean flour and rice flour could be seen in Table 1 . The mixture of flour for each formula and refined sugar were mixed. Then, butter and vanilla were added to the dough. The mixture was stirred until smooth. After that, the water and the ingredients were added to the dough and mixed with hands. The dough was flattened on a baking sheet and then baked in an oven (Memmert UN 110 , Germany) with a temperature of $150^{\circ} \mathrm{C}$ for 20 mins. After that, the snack bars were dried and cut. Then put into a plastic zipper that has been coated with aluminium foil and stored at room temperature for further analysis.

Table 1. The ratio of black soybean flour and black rice flour

\begin{tabular}{ccc}
\hline Formula & Black soybean flour $(\%)$ & Black rice flour $(\%)$ \\
\hline 1 & 30 & 70 \\
2 & 50 & 50 \\
3 & 70 & 30 \\
\hline
\end{tabular}

Source: Pramitasari et al. (2018)

\subsection{Sensory evaluation}

Sensory evaluation of the three variations of black rice and black soybean snack bars was carried out with the acceptance test using a hedonic scale. Attributes tested include aroma, taste, texture, and overall acceptance with a scale of 1-9 (very, very dislike - very, very like). The snack bars were tested by 40 naïve consumers with 18-22 years male and female (Kemp et al., 2009).

\subsection{Analysis of total monomeric anthocyanin content}

Anthocyanins extraction was carried out according to the method of Shao et al. (2014). Anthocyanins in the three snack bar formulas were extracted using methanol (Merck, Germany) and $\mathrm{HCl}$ (Merck, Germany) solvents. Black soybean flour and black rice flour were extracted as a control. Extraction was carried out of $12 \mathrm{~g}$ of the sample divided into four conical tubes. Samples were mashed and extracted using $10 \mathrm{~mL} 80 \%$ (v/v) methanol containing $0.01 \mathrm{~mL}$ concentrated $\mathrm{HCl} 37 \%$ (v v) per $1 \mathrm{~g}$ of sample. The mixture was stirred using an orbital shaker (Thermo Fisher, USA) in dark conditions at a speed of $120 \mathrm{rpm}$ for one hour at room temperature. The mixture was centrifuged (Eppendorf 5430, Germany) at a speed of $2000 \mathrm{~g}$ for $10 \mathrm{mins}$ at room temperature. The supernatant, an anthocyanins extract, was filtered using filter paper no. 1 (Whatman, UK). After that, the solvent was evaporated using a rotary evaporator (Buchi R-300, Germany) at $40{ }^{\circ} \mathrm{C}$. Then, the extract was dried in a fume 
hood (Biobase, China) for 24 hrs. After the solvent has evaporated, the extract was taken and weighed (Shimadzu, Japan).

Absorbance (A) was calculated by Equation (1):

$\mathrm{A}=[(\mathrm{A} 520 \mathrm{~nm}-\mathrm{A} 700 \mathrm{~nm}) \mathrm{pH} 1.0]-[(\mathrm{A} 520 \mathrm{~nm}-$ A700 nm) pH 4.5]

Total monomeric anthocyanin content was calculated by Equation (2) as mg cyanidin-3-glucoside equivalent per g dried weight:

Total anthocyanin content $=\frac{\mathrm{A} \times \mathrm{MW} \times \mathrm{DF} \times 1000}{\varepsilon \times \mathrm{L}}$

Where $\mathrm{A}=$ measured absorbance value $\left(\mathrm{A}=\left(\mathrm{A}_{520 \mathrm{~nm}}\right.\right.$ $\left.\left.-\mathrm{A}_{700 \mathrm{~nm}}\right) \mathrm{pH} 1.0-\left(\mathrm{A}_{520 \mathrm{~nm}}-\mathrm{A}_{700 \mathrm{~nm}}\right) \mathrm{pH} 4.5\right), \mathrm{MW}=$ molecular weight for cyanidin-3-glucoside $(449.2 \mathrm{~g} /$ $\mathrm{mol}), \mathrm{DF}=$ dilution factor, $\varepsilon=$ Molar absorbance unit of cyanidin-3-glucoside $(26,900 \mathrm{~L} /(\mathrm{cm} . \mathrm{mol}), \mathrm{L}=$ cuvette length $(1 \mathrm{~cm})$ and $1000=$ conversion factor from milliliters to liters

\subsection{Analysis of probiotic and pathogenic bacteria growth}

Measurement of bacterial growth was performed on all three snack bar formulas based on Moore (2011) with several modifications. MRSA media was used to grow $L$. acidophilus under anaerobic conditions using the anaerobic jar (Oxoid, UK) equipped with anaerogen gas pack. They were then incubated at $37 \mathrm{C}$ for $48 \mathrm{hrs}$. A bacterial colony was then transferred to $10 \mathrm{~mL}$ of MRSB media and incubated at $37^{\circ} \mathrm{C}$ for $24 \mathrm{hrs}$. For pathogenic bacteria, E. coli and $S$. enterica ser. Typhi were grown on NA media and incubated at $37^{\circ} \mathrm{C}$ for $48 \mathrm{hrs}$. After that, each pathogenic bacteria colony was transferred in $10 \mathrm{~mL}$ of $0.85 \%$ physiological salt solution and incubated at $37^{\circ} \mathrm{C}$ for $24 \mathrm{hrs}$.

Samples were prepared by taking $0.2 \mathrm{~g}$ of anthocyanins extracted from the snack bar and placed in a sterile conical tube. As much as $0.4 \mathrm{~mL}$ of liquid media was added (MRSB for L. acidophilus and $0.85 \%$ physiological salt solution for pathogenic bacteria). Then, $100 \mu \mathrm{L}$ of bacteria were added and homogenized using vortex (Thermo Fisher, USA). After that, the mixture was diluted by mixing $100 \mu \mathrm{L}$ of the mixture into $900 \mu \mathrm{L}$ of $0.85 \%$ physiological salt. Then, as much as $100 \mu \mathrm{L}$ of the mixture spread onto MRSA (for $L$. acidophilus) or NA (for pathogenic bacteria). They were then incubated (Memmert, Germany) at $37^{\circ} \mathrm{C}$ for $48 \mathrm{hrs}$. The number of colonies was then calculated. Replication was done twice.

\subsection{Statistic analysis}

The software used for statistical analysis was IBM SPSS version 25. Analysis of variance (ANOVA) followed by Tukey's test was used with a significant level at $\mathrm{P}<0.05$.

\section{Results and discussion}

\subsection{Snack bars}

Qualitatively, the difference between the three snack bar variations was quite noticeable seen using naked eyes in colour. The snack bar with the highest concentration of black rice had more dark colours than other variations. Its dark colour indicates the higher anthocyanin that gives a blackish-purple colour in black rice flour than black soybean (Table 3 ). High temperature during baking has also changed the colour of the dough making it a darker brown colour due to thermal degradation of anthocyanin, as well as Maillard reaction between amino acids and reducing sugar, which formed brown polymers, namely melanoidins (Žilić et al., 2016)

\subsection{Sensory acceptance}

Based on the sensory evaluation (Table 2), colour acceptance in formula 3 was significantly higher $(\mathrm{p}=$ 0.00 ) than in formulas 1 and 2. Its colour tends to be brighter, which is seen using the naked eye instead of other formulas since it contained less black rice. Lavin and Lawless (1998) reported that colour could influence consumer acceptance in wines with the same sweetness level treated with different colours. The results showed that the colour of dark red wine felt sweeter than the colour of wine with bright red by adult panellists. It indicated that the colour could influence the taste, supporting the sensory acceptance of the product.

Formula 3 showed significantly higher taste and overall acceptance than formula $1(\mathrm{P}=0.01)$. It could be caused by higher black soybean content compared to other formulas. Black soybean contained high amino acid, especially glutamic acid, that contributes to umami

Table 2. Consumer acceptance of snack bars

\begin{tabular}{ccccccc}
\hline Sample & Colour & Aroma & Texture & Taste & After taste & Overall \\
\hline Formula 1 & $4.93 \pm 1.44^{\mathrm{a}}$ & $5.74 \pm 1.53^{\mathrm{a}}$ & $5.58 \pm 1.78^{\mathrm{a}}$ & $5.9 \pm 1.72^{\mathrm{a}}$ & $5.35 \pm 1.79^{\mathrm{a}}$ & $5.88 \pm 1.42^{\mathrm{a}}$ \\
Formula 2 & $5.60 \pm 1.32^{\mathrm{a}}$ & $6.18 \pm 1.41^{\mathrm{a}}$ & $6.15 \pm 1.47^{\mathrm{a}}$ & $6.13 \pm 1.38^{\mathrm{ab}}$ & $5.30 \pm 1.54^{\mathrm{a}}$ & $6.13 \pm 1.27^{\mathrm{b}}$ \\
Formula 3 & $6.35 \pm 1.34^{\mathrm{b}}$ & $6.00 \pm 1.34^{\mathrm{a}}$ & $6.35 \pm 1.55^{\mathrm{a}}$ & $6.73 \pm 1.43^{\mathrm{b}}$ & $6.13 \pm 1.40^{\mathrm{a}}$ & $6.75 \pm 1.28^{\mathrm{b}}$ \\
\hline
\end{tabular}

Values are presented as mean \pm standard deviation $(\mathrm{n}=40)$. Values with different superscript within the same column are significantly different $(\mathrm{P}<0.05)$. 
flavour, which forms a savoury taste. Nurrahman (2015) reported glutamic acid content in Malika black soybean reached $98.75 \pm 14.30 \mathrm{mg} / \mathrm{g}$, higher than yellow soybean. Nurrahman et al. (2012) also revealed that the consumer preference for black soybean tempeh was higher than yellow soybean tempeh. In line with this finding, consumer acceptance increased in snack bars with higher black soybean content.

Consumer acceptance of the aroma attribute was not significantly different from "quite like" ratings. The snack bar formulas contained sugar and were made by baking at $150^{\circ} \mathrm{C}$. It could trigger a non-enzymatic reaction when the sugar was heated and reacted with the water. When heated, sucrose was split into glucose and fructose, then dehydrated. Molecules lose water and react with each other, forming an aromatic component that could affect the aroma (Kroh, 1994). Black rice and black soybean were also contributed to producing ricelike and beany flavour due to their aroma-active compounds (Ayele, et al., 2017; Boeswetter et al., 2019).

Consumers quite prefer the texture of all snack bars. The hardness of snack bars could be influenced by the main ingredients used. The texture was more rigid in the snack bar with higher black soybean. It could be caused by the protein content of black soybean, which was relatively high compared to black rice. Protein could bind to starch to form aggregates and block bonds with water (Sarabhai et al., 2015). Contrary to the higher content of the black soybean snack bar, the higher content of black rice performed soft texture. Black rice contained amylose and amylopectin, which is reacted with water to form hydrogen bonds. These bonds have an excellent ability to absorb water, which contributes to producing soft texture in food products (Itthivadhanapong and Sangnark, 2016). Although a snack bar with higher black soybean content was more rigid, it did not affect the level of consumer acceptance. According to Muñoz and Civille (1987), several types of food products had an excellent tolerance for their texture, such as candy, which could be soggy or hard. There were even commercially available snack bars that are hard or soft, that had a high tolerance level on texture attributes.

\subsection{Total monomeric anthocyanin content}

The total monomeric anthocyanin content showed no significant difference in these three samples (Table 3). However, all three samples showed a significant difference in total monomeric anthocyanin content $(\mathrm{P}=$ 0.00) compare to black soybean and black rice flour. It might happen due to the process carried out in making snack bars. These snack bars have been mixed with various ingredients, making the proportion of anthocyanin content was decrease. Snack bars were also roasted at $150^{\circ} \mathrm{C}$ that degraded the anthocyanins. On account of anthocyanins being stable at $4{ }^{\circ} \mathrm{C}$ and will deteriorate at $50^{\circ} \mathrm{C}$ (Rakkimuthu et al., 2016). Besides, anthocyanins characteristic is also light-sensitive. It will degrade easily after light exposure (Moldovan et al., 2012)

Table 3. Results of analysis of total anthocyanin content

\begin{tabular}{cc}
\hline Sample & Total anthocyanin content $(\mathrm{mg} / \mathrm{g})$ \\
\hline Formula 1 & $0.30 \pm 0.03^{\mathrm{a}}$ \\
Formula 2 & $0.21 \pm 0.05^{\mathrm{a}}$ \\
Formula 3 & $0.18 \pm 0.04^{\mathrm{a}}$ \\
Black soybean flour & $0.83 \pm 0.14^{\mathrm{b}}$ \\
Black rice flour & $2.40 \pm 0.21^{\mathrm{c}}$ \\
\hline
\end{tabular}

Values are presented as mean \pm standard deviation $(n=2)$. Values with different superscript within the same column are significantly different $(\mathrm{P}=0.00)$.

\subsection{Probiotic and pathogen growth analysis}

Based on Table 4, all snack bars could inhibit the growth of pathogenic bacteria (E. coli and $S$. enterica ser. Typhi) and probiotic bacteria ( $L$. acidophilus). Therefore, these samples could not be used as a prebiotic product due to the inhibition of $L$. acidophilus even though its inhibitory property was significantly lower than the inhibition to pathogenic bacteria $(\mathrm{P}=0.00)$. Based on these results, the capability of the snack bars as an antimicrobial agent due to their ability to inhibit the growth of pathogenic bacteria used in this study was the main focus. These antimicrobial properties came from anthocyanin content since anthocyanins could reduce the growth of $E$. coli and $S$. enterica ser. Typhi bacteria by disrupting the cell walls. Lacombe et al. (2010) reported E. coli O157: H7 undergoes disintegration and irregularity in the outer membrane and cytoplasmic leakage caused by anthocyanins. The antimicrobial capacity of anthocyanins was thought to be due to their phenolic structure, which could inhibit the activity of beta-glucans enzymes making up the cell wall (Naz et al., 2007).

Table 4. Inhibition of growth of $L$. acidophilus, S. enterica ser. Typhi, and E. coli bacteria to the samples

\begin{tabular}{lccc}
\hline \multirow{2}{*}{ Samples } & \multicolumn{3}{c}{ Bacteria } \\
\cline { 2 - 4 } & L. acidophilus & $\begin{array}{c}\text { S. enterica ser. } \\
\text { Typhi }\end{array}$ & E. coli \\
\hline Formula 1 & $54.13 \pm 0.58^{\mathrm{Aa}}$ & $99.94 \pm 0.92^{\mathrm{Ab}}$ & $99.84 \pm 0.01^{\mathrm{Ab}}$ \\
Formula 2 & $29.34 \pm 0.58^{\mathrm{Ba}}$ & $99.88 \pm 0.18^{\mathrm{Ab}}$ & $99.84 \pm 0.23^{\mathrm{Ab}}$ \\
Formula 3 & $2.07 \pm 1.76^{\mathrm{Ca}}$ & $95.92 \pm 0.23^{\mathrm{Bb}}$ & $90.77 \pm 1.15^{\mathrm{Bb}}$ \\
\hline
\end{tabular}

Values are presented as mean \pm standard deviation $(n=2)$. Values with different superscript within the same column are significantly different $(\mathrm{P}=0.00)$.

The results also showed that $L$. acidophilus growth was significantly more inhibited $(\mathrm{P}=0.00)$ when grown on extract containing higher black rice. According to Avila et al. (2009), L. acidophilus had different 
degradation abilities in delphinidin-3-glucoside and malvinidin-3-glucoside incubated for 24 hours. It could indicate that the type of anthocyanin affects the level of bacterial cell wall degradation. The kinds of anthocyanins contained in black rice and black soybean were different. In black soybeans, the types of main anthocyanins contained were delphinidin-3-glucoside, cyanidin-3-glucoside, and petunidin-3-glucoside (Lee et al., 2020). Whereas in black rice, its main anthocyanin type was cyanidin-3-glucoside (Bae et al., 2017).

Inhibition of bacterial growth was also influenced by the smallest concentration of antimicrobial substances to inhibit growth or called the Minimum Inhibitory Concentration (MIC) (Lacombe et al., 2010). The extracts of formulas 1 and 2 were not significantly different in inhibiting E. coli and S. enterica ser. Typhi, but they were significantly higher than formula 3, indicating that the concentration of antimicrobial substances contained in formula 1 and 2 might be higher and might meet the smallest concentration of substances to inhibit the two bacteria. Lacombe et al. (2010) reported MIC of E. coli $\mathrm{O} 157: \mathrm{H} 7$ was $14.8 \mathrm{mg} / \mathrm{L}$ in anthocyanin and $2.7 \mathrm{~g} / \mathrm{L}$ in phenolic.

Lactobacillus acidophilus growth inhibition was thought to be due to other compounds extracted in the methanol $+\mathrm{HCl}$ solvent. The snack bars consisted of various ingredients that could be extracted in a methanol $+\mathrm{HCl}$ solvent. Teets et al. (2009) reported methanol + $\mathrm{HCl}$ solvent could extract flavonols, phenolic acids, and flavonoids from almonds, one of the snack bar ingredients. According to Ordaz et al. (2017), a single phenolic component could increase the growth of $L$. acidophilus. However, the combination of several phenolic components has been shown to inhibit the growth of $L$. acidophilus but this mechanism of inhibition was not known. Further studies are needed to determine the antimicrobial components that were extracted from the snack bars. This study saw the potential of antibacterial activity from the samples used as a natural preservative agent for the snack bars themselves.

\section{Conclusion}

The three snack bars formulas as a whole have different qualitative appearances. The total anthocyanin content in the three snack bars had no differences. Anthocyanins contained in snack bars had a significantly more considerable percentage of inhibition against $E$. coli and $S$. enterica ser. Typhi than L. acidophilus $(\mathrm{P}=$ $0.00)$. The percentage of $E$. coli and $S$. enterica ser. Typhi inhibition in formulas 1 and 2 was significantly higher than formula 3 , with rates approaching $100 \%(\mathrm{P}=$
$0.00)$. Formula 2 was the best snack bar according to the inhibition ability against pathogenic bacteria and the sensory acceptance. Based on this study, snack bars based on black soybean and black rice may have potential as a natural preservation agent for snack bars themselves. However, further research is needed to study their activity against various pathogenic bacteria related to food spoilage.

\section{Conflict of interest}

The authors declare no conflict of interest.

\section{Acknowledgments}

The authors are thankful to Faculty of Biotechnology, Atma Jaya Catholic University of Indonesia, for providing facilities and financial support for this research work.

\section{References}

Avila, M., Hidalgo, M., Sanchez-Moreno, C., Pelaez, C., Requena, T. and de Pascual-Teresa, S. (2009). Bioconversion of anthocyanin glycosides by Bifidobacteria and Lactobacillus. Food Research International, 42(10), 1453-1461. https:// doi.org/10.1016/j.foodres.2009.07.026

Ayele, H.H., Bultosa, G., Abera, T. and Astatkie, T. (2017). Nutritional and sensory quality of wheat bread supplemented with cassava and soybean flours. Cogent Food and Agriculture, 3(1), 1-13. https://doi.org/10.1080/23311932.2017.1331892

Bae, I.Y., An, J.S., Oh, I.K. and Lee, H.G. (2017). Optimized preparation of anthocyanin-rich extract from black rice and its effects on in vitro digestibility. Food Science and Biotechnology, 26 (5), 1415-1422. https://doi.org/10.1007/s10068-0170188-x

Boeswetter, A.R., Scherf, K.A., Schieberle, P. and Koehler, P. (2019). Identification of the key aroma compounds in gluten-free rice bread. Journal of Agricultural and Food Chemistry, 67(10), 29632972. https://doi.org/10.1021/acs.jafc.9b00074

Euromonitor International (EI). (2020). Consumer Foodservice in Indonesia. Retrieved on February 13, 2021 from EI Website: https:// www.euromonitor.com/consumer-foodservice-inindonesia/report

International Food Information Council (IFIC). (2016). Food and Health Survey: "Food Decision 2016: The Impact of a Growing National Food Dialogue". Retrieved on February 12, 2021 from IFIC Website: https://foodinsight.org/2016-food-and-health-survey- 
food-decision-2016-the-impact-of-a-growingnational-food-dialogue/

Itthivadhanapong, P. and Sangnark, A. (2016). Effects of substitution of black glutinous rice flour for wheat flour on batter and cake properties. International Food Research Journal, 23(3), 1190-1198.

Kemp, S.E., Hollowood, T. and Hort, J. (2009). Sensory evaluation: a practical handbook. United Kingdom: Blackwell Publishing. https:// doi.org/10.1002/9781118688076

Kroh, L.W. (1994). Caramelisation in food and beverages. Food Chemistry, 51(4), 373-379. https:// doi.org/10.1016/0308-8146(94)90188-0

Lacombe, A., Wu, V. C. H., Tyler, S. and Edwards, K. (2010). Antimicrobial action of the American cranberry constituents; phenolics, anthocyanins, and organic acids, against Escherichia coli O157:H7. International Journal of Food Microbiology, 139(12), 102-107. https://doi.org/10.1016/ j.ijfoodmicro.2010.01.035

Lavin, J.G. and Lawless, H.T. (1998). Effects of color and odor on judgments of sweetness among children and adults. Food Quality and Preference, 9(4), 283289. https://doi.org/10.1016/S0950-3293(98)00009-3

Lee, K.J., Baek, D.Y., Lee, G.A., Cho, G.T., So, Y.S., Lee, J.R., Ma, K.H., Chung, J.W. and Hyun, D.Y. (2020). Phytochemicals and antioxidant activity of Korean Black Soybean (Glycine max L.) Landraces. Antioxidants, 9(3), 213. https://doi.org/10.3390/ antiox9030213

Ma, Y., Ding, S., Fei., Y., Liu, G., Jang, H. and Fang, J. (2019). Antimicrobial activity of anthocyanins and catechins against foodborne pathogens Escherichia coli and Salmonella. Food Control, 106, 106712. https://doi.org/10.1016/j.foodcont.2019.106712

Moldovan, B., David, L., Chrisbora, C. and Cimpoiu, C. (2012). Degradation kinetics of anthocyanins from European Cranberrybush (Viburnum opulus L.) fruit extracts. Effects of temperature, $\mathrm{pH}$, and storage solvent. Molecules, 17(10), 11655-11666. https:// doi.org/10.3390/molecules171011655

Moore, K.E. (2011). Biological analysis of prebiotics in various processed food matrices. Lincoln: University of Nebraska, PhD Dissertation.

Muñoz, A.M. and Civille, G.V. (1987). Factors affecting perception and acceptance of food texture by American consumers. Food Reviews International, 3 (3), 285-322. https:// doi.org/10.1080/87559128709540817

Naz, S., Siddiqi, R., Ahmad, S., Rasool, S.A. and Sayeed, S.A. (2007). Antibacterial activity directed isolation of compounds from Punica granatum.
Journal of Food Science, 72(9), 341-345. https:// doi.org/10.1111/j.1750-3841.2007.00533.x

Nurrahman, Astuti, M., Suparmo. and Soesatyo, M.H.N.E. (2012). Pertumbuhan jamur, sifat organoleptik dan aktivitas antioksidan tempe kedelai hitam yang diproduksi dengan berbagai jenis inokulum. Agritech, 32(1), 60-65. [In Bahasa Indonesia].

Nurrahman. (2015). Evaluasi komposisi zat gizi dan senyawa antioksidan kedelai hitam dan kedelai kuning. Jurnal Aplikasi Teknologi Pangan, 4(3), 8992. [In Bahasa Indonesia]. https://doi.org/10.17728/ jatp.v4i3.133

Ordaz, R.P., Medrano, A.W., Goñi, M.G., Montfort, G.R.C., Zavala, J.F.A. and Aguilar, G.A.G. (2017). Effect of phenolic compounds on the growth of selected probiotic and pathogenic bacteria. Letters in Applied Microbiology, 66(1), 25-31. https:// doi.org/10.1111/lam.12814

Pang, Y., Ahmed, S., Xu, Y., Beta, T., Zhu, Z., Shao, Y. and Bao, J. (2018). Bound phenolic compounds and antioxidant properties of whole grain and bran of white, red and black rice. Food Chemistry, 240, 212221. https://doi.org/10.1016/j.foodchem.2017.07.095

Pervaiz, T., Songtao, J., Faghihi, F., Halder, M.S. and Fang, J. (2017). Naturally occurring anthocyanin, structure, functions and biosynthetic pathway in fruit plants. Journal of Plant Biochemistry and Physiology, 5(2), $1000187 . \quad \mathrm{https} / / /$ doi.org/10.4172/2329-9029.1000187

Pramitasari, R., Ivana, I. and Yanti. (2018). Development of snack bar from black soybean and black rice for breastfeeding mothers. International Journal of Engineering and Technology, 7, 288-291. https:// doi.org/10.14419/ijet.v7i4.14.27583

Rakkimuthu, R., Palmurugan, S. and Shanmugapriya, A. (2016). Effect of temperature, light, $\mathrm{pH}$ on the stability of anthocyanin pigments in Cocculus hirsutus fruits. International Journal of Multidisciplinary Research and Modern Education, 2(2), 2454-6119.

Sarabhai, S., Indrani D., Vijaykrishnaraj, M., Milind, Kumar, V.A. and Prabhasankar, P. (2015). Effect of protein concentrates, emulsifier on textural and sensory characteristics of gluten free cookies and its immunochemical validation. Journal of Food Science Technology, 52(6), 3763-3772. https:// doi.org/10.1007/s13197-014-1432-5

Shao, Y. F., Xu, F., Bao, J.S. and Beta T. (2014). Identification and quantification of phenolic acids and anthocyanins as antioxidants in bran, embryo, and endosperm of white, red, and black rice kernels 
(Oryza sativa L.). Journal of Cereal Science, 59(2), 211-218. https://doi.org/10.1016/j.jcs.2014.01.004

Teets, A.S., Minardi, C.S., Sundararaman, M., Hughey, C.A. and Were, L.M. (2009). Extraction, identification of flavonoids and phenolic acids in electron beam-irradiated almond skin powder. Journal of Food Science, 74(3), 298-305. https:// doi.org/10.1111/j.1750-3841.2009.01112.x

The Nielsen Company. (2014). Snack Attack: What Consumers are Reaching for Around the World. Retrieved on February 13, 2021 from Nielsen Website: https://www.nielsen.com/wp-content/ uploads/sites/3/2019/04/

Nielsen20Global20Snacking20Report20September2 02014-3.pdf

Thielmann, J., Kohnen, S. and Hauser, C. (2017). Antimicrobial activity of Olea europaea Linné extracts and their applicability as natural food preservative agents. International Journal of Food Microbiology, 251, 48-66. https://doi.org/10.1016/ j.ijfoodmicro.2017.03.019

USDA. (2016). Copy of National Nutrient Database for Standard Reference about Nutri-Grain Fruit and Nut Bar. Washington, D.C (US): USDA.

Žilić, S., Kocadağh, T., Vančetović, J. and Gőkmen, V. (2016). Effects of baking conditions and dough formulations on phenolic compound stability, antioxidant capacity and color of cookies made from anthocyanin-rich corn flour. LWT-Food Science and Technology, 65, 597-603. https://doi.org/10.1016/ j.lwt.2015.08.057 